\title{
Effect of Zinc applications on Grain Yield, Straw Yield and Harvest Index in kharif Rice (Oryza sativa L.) Genotypes
}

\author{
Vivek N. Zinzala* and Ajay V. Narwade \\ Department of Genetics and Plant Breeding, Navsari Agricultural University, \\ Navsari -396450 (Gujarat), India \\ *Corresponding author
}

\section{A B S T R A C T}

Keywords

Rice, Zinc, Soil, Foliar application

Article Info

Accepted:

04 October 2019

Available Online:

10 November 2019
A field experiment was carried out at college farm, Navsari Agricultural University, Navsari, during kharif seasons of 2017 and 2018. The experiment was laid out in a randomized block design with factorial concept and replicated thrice. The experiment consisted of three varieties viz., IET-25450 $\left(\mathrm{V}_{1}\right)$, BPT-5204 $\left(\mathrm{V}_{2}\right)$ and IET-24766 $\left(\mathrm{V}_{3}\right)$, three soil base zinc application $\left(\mathrm{S}_{1}\right)$ control $\left(00 \mathrm{~kg} \mathrm{ZnSO}_{4} \mathrm{ha}^{-1}\right),\left(\mathrm{S}_{2}\right) 10 \mathrm{~kg} \mathrm{ZnSO}_{4} \mathrm{ha}^{-1}$ at the time of transplanting and $\left(\mathrm{S}_{3}\right) 20 \mathrm{~kg} \mathrm{ZnSO} \mathrm{Zn}^{-1}$ at the time of transplanting and two foliar $\mathrm{Zn}$ application $\left(\mathrm{F}_{1}\right) 0 \% \mathrm{Zn}$ EDTA and $\left(\mathrm{F}_{2}\right) 1 \%$ Zn EDTA spray at tillering and grain filling stage. Among the varieties, IET-24766 gave significantly higher grain and straw yield and harvest index followed by IET-25450 and BPT-5204 and soil base zinc application of $20 \mathrm{~kg} \mathrm{ZnSO}_{4} \mathrm{ha}^{-1}$ at the time of transplanting as well as foliar zinc application of $1 \% \mathrm{Zn}$ EDTA spray at tillering and grain filling stage resulted in higher values in grain and straw yield and harvest index during in pooled analysis.

\section{Introduction}

Rice (Oryza sativa L.) remains the staple food for nearly half the world's population, most of them living in Asia, and many of them among the poorest people in the world (Fischer 1998). In Asia, rice is the premier food crop and foremost cereal and therefore, food security largely depends on productivity of the rice ecosystem. India is first in terms of area (43.79 mha) and second in production (168.50 $\mathrm{mt}$ ) of paddy, next only to China. However, the average productivity of paddy in India is only (3.85 $\left.\mathrm{t} \mathrm{ha}^{-1}\right)$ compared with a world average of $4.60 \mathrm{t} \mathrm{ha}^{-1}$, still well below the world average, although increasingly marginally (FAO 2017). Micronutrient deficiencies are becoming serious because of 
escalated nutrient demand from more intensive and exploitative agriculture, coupled with use of single-nutrient fertilizers and low amounts of organic manures (Savithri, 1999). The Food and Agriculture Organization (FAO) has determined that zinc is the most commonly deficient micronutrient in agricultural soils. Analysis of over 256,000 soil samples from all over India showed that about $50 \%$ of the soils were deficient in zinc and that this was the most common micronutrient problem affecting crop yields in India (Singh, 2009). In rice, low plantavailable $\mathrm{Zn}$ in soil causes leaf bronzing and poor tillering at the early growth stages, leading to delayed maturity and significant yield loss (Neue et al., 1998 and Dobermann and Fairhurst, 2000). The main cause of deficiency of plant available $\mathrm{Zn}$ in soil is the precipitation or adsorption of $\mathrm{Zn}$ with various soil components, depending on the $\mathrm{pH}$ and redox potential (Impa and Johnson-Beebout, 2012). Zinc is one of the essential micronutrients, which serves as a co-factor for many enzymes involved in the metabolism of carbohydrates, lipids, proteins, and nucleic acids, hence is important for normal growth and development of plants and animals (Roohani et al., 2013 and Sadeghzadeh, 2013). In rice, low plant-available $\mathrm{Zn}$ in soil causes leaf bronzing and poor tillering at the early growth stages, leading to delayed maturity and significant yield loss (Neue et al., 1998 and Dobermann and Fairhurst 2000). $\mathrm{Zn}$ is commonly applied in rice under lowland condition before flooding or after transplanting to prevent $\mathrm{Zn}$ deficiency and for increased grain yield (Dobermann and Fairhurst, 2000 and Naik and Das, 2007).

Most common method of $\mathrm{Zn}$ fertilization is through soil application. $\mathrm{Zn}$ can be applied to soil by broadcasting, banding in vicinity of seed, or via irrigation. $\mathrm{Zn}$ is commonly applied in rice under lowland condition before flooding or after transplanting to prevent $\mathrm{Zn}$ deficiency and for increased grain yield (Dobermann and Fairhurst, 2000 and Naik and Das, 2007). The main cause of deficiency of plant available $\mathrm{Zn}$ in soil is the precipitation or adsorption of $\mathrm{Zn}$ with various soil components, depending on the $\mathrm{pH}$ and redox potential (Impa and Johnson-Beebout, 2012). Amongst different methods, the foliar spray of zinc is an efficient one for enhancement of crop productivity. Foliar application of $\mathrm{Zn}$ post flowering is effective in increasing zinc in rice grains (Boonchuay et al., 2013 and Yuan et al., 2013). Applying Zn to the soil and treating seeds or plants increase plant yields (Naik and Das, 2007; Shivay et al., 2008 and Rehman et al., 2012). Results reported by (Mahmoodi and Mogadam, 2015) showed that the increasing $\mathrm{Zn}$ concentration in foliar application, increased yield and yield components of rice significantly. Foliar application of nutrients has become an efficient way to increase yield and quality of crops (Roemheld and El-Fouly, 1999). The aim of this experiment was to study effect of $\mathrm{Zn}$ applications on grain yield, straw yield and harvest index in kharif rice genotypes.

\section{Materials and Methods}

A field experiment was conducted at college farm, Navsari Agricultural University, Navsari, Gujarat, India during kharif seasons of 2017 and 2018. The experiment consisted of three varieties viz., IET-25450 $\left(\mathrm{V}_{1}\right)$, BPT$5204\left(\mathrm{~V}_{2}\right)$ and IET-24766 $\left(\mathrm{V}_{3}\right)$, three soil base zinc application $\left(\mathrm{S}_{1}\right)$ control $\left(00 \mathrm{~kg} \mathrm{ZnSO}_{4}\right.$ $\left.\mathrm{ha}^{-1}\right),\left(\mathrm{S}_{2}\right) 10 \mathrm{~kg} \mathrm{ZnSO}{ }_{4} \mathrm{ha}^{-1}$ at the time of transplanting and $\left(\mathrm{S}_{3}\right) 20 \mathrm{~kg} \mathrm{ZnSO}_{4} \mathrm{ha}^{-1}$ at the time of transplanting followed by two foliar $\mathrm{Zn}$ application $0 \% \mathrm{Zn}$ EDTA $\left(\mathrm{F}_{1}\right)$ and $1 \% \mathrm{Zn}$ EDTA $\left(\mathrm{F}_{2}\right)$ spray at tillering and grain filling stage was laid out in randomized block design with factorial concept and replicated thrice with an objective to study the effect of $\mathrm{Zn}$ application on grain and straw yield and harvest index in rice genotypes. Other 
recommended agronomical practices in vogue were followed for reaping good crop.

The crop was harvested at full maturity when $80-90 \%$ of the grains were turned into straw colored. The crop was cut at the ground level and plot wise crop was bundled separately and brought to the threshing floor. Grains and straw yield obtained from each unit plot were sun-dried and weighed carefully. The dry weight of grains and straw of five sample plants were added to the respective unit plot yield to record the final grain yield plot $^{-1}$ and grain yield per plant. The summation of grain and straw yield were considered as biological yield. Harvest index was calculated from the grain and straw yield of rice for each plot and expressed in percentage.

The observations recorded during the course of investigation were tabulated and analyzed statistically to draw a valid conclusion. The data were analyzed as per the standard procedure of "Analysis of Variance" (ANOVA) as described by Gomez and Gomez (1984). The significance of treatments was tested by ' $F$ ' test (Variance ratio). Standard error of mean (S.Em. \pm ) was computed for various factors. Critical difference (CD) was used to know the differences exist between treatment mean at 5\% level of significance where ' $F$ ' test showed significant differences among means by the following formula: C.D. $=$ S.E. $(\mathrm{d}) \times \mathrm{t}_{0.05}$, edf

\section{Results and Discussion}

\section{Grain and straw yield per plant}

The two year and pooled paddy yield data are presented in Table 1 and Figure 1 and 2. Scrutiny of data revealed that varietal effect is significantly different for grain yield and straw yield per plant similar trend was recorded during first and second year of investigation. The varieties IET-24766 $\left(\mathrm{V}_{3}\right)$ produced higher mean grain yield per plant (19.12 g) and straw yield per plant $(23.37 \mathrm{~g})$. But, grain and straw yield per plant of variety IET-24766 $\left(\mathrm{V}_{3}\right)$ was statistically at par with variety IET-25450 $\left(\mathrm{V}_{1}\right)$. While, significantly lower mean grain yield per plant (16.28 g) and straw yield per plant $(21.18 \mathrm{~g})$ registered under variety BPT$5204\left(\mathrm{~V}_{2}\right)$.

The perusal of the data clearly indicated that soil base zinc application influenced the grain yield per plant of rice during both the years. Amongst zinc application, application of 20 $\mathrm{kg} \mathrm{ZnSO} \mathrm{ha}^{-1}\left(\mathrm{~S}_{3}\right)$ at the time of transplanting recorded higher mean grain yield per plant $(18.80 \mathrm{~g})$ and straw yield per plant $(23.41 \mathrm{~g})$ over other soil base zinc application treatments. However, it was statistically at par with $\left(\mathrm{S}_{2}\right) 10 \mathrm{~kg} \mathrm{ZnSO}_{4} \mathrm{ha}^{-1}$ at the time of transplanting. Minimum mean grain yield per plant $(16.88 \mathrm{~g})$ and straw yield per plant $(21.39 \mathrm{~g})$ were recorded in control $\left(\mathrm{S}_{1}\right) 00 \mathrm{~kg}$ $\mathrm{ZnSO}_{4} \mathrm{ha}^{-1}$.

Foliar zinc application produced significant variation on grain and straw yield per plant. Treatment $1 \%$ Zn EDTA at tillering and grain filling stage proved significantly maximum mean grain yield per plant (18.55 g) and straw yield per plant $(23.04 \mathrm{~g})$. The lowest grain yield per plant $(17.06 \mathrm{~g})$ and straw yield per plant (21.75 g) recorded under $0 \%$ Zn EDTA.

The interaction effects in respect of Grain and straw yield per plant and harvest index between variety and soil base $\mathrm{Zn}$ application (V x S), variety and foliar Zn application (V x $\mathrm{F})$, soil base $\mathrm{Zn}$ application and foliar $\mathrm{Zn}$ application ( $\mathrm{S} \times \mathrm{F}$ ) and variety, soil base $\mathrm{Zn}$ application and foliar $\mathrm{Zn}$ application ( $\mathrm{V} \times \mathrm{S} \times$ F) were dose not show any significant effect in individual years of investigation and in pooled analysis.

The increase in grain and straw yield with application of zinc may be attributed to 
adequate supply of zinc that might have increased the availability and uptake of other essential nutrients resulting in improvement in metabolic activities and also due to the effect of zinc on the proliferation of roots. Similar findings were also reported by (Muthukumararaja et al., 2013).

\section{Grain and straw yield $\mathrm{kg}$ per plot and harvest index}

The two year and pooled paddy yield data are presented in Table 1 and Figure 3, 4 and 5. Scrutiny of data revealed that varietal effect is significantly different for grain yield and straw yield $\mathrm{kg}$ per plot similar trend was recorded during first and second year of investigation. The varieties IET-24766 $\left(\mathrm{V}_{3}\right)$ produced higher mean grain yield $\mathrm{kg}$ per plot (5.47) and straw yield kg per plot (6.68) Harvest index dose not shows significant effect. But, grain and straw yield $\mathrm{kg}$ per plot of variety IET-24766 $\left(\mathrm{V}_{3}\right)$ was statistically at par with variety IET-25450 $\left(\mathrm{V}_{1}\right)$. While, significantly lower mean grain yield $\mathrm{kg}$ per plot (4.66) and straw yield $\mathrm{kg}$ per plot (6.06) registered under variety BPT-5204 $\left(\mathrm{V}_{2}\right)$.

The perusal of the data clearly indicated that soil base zinc application influenced the grain yield $\mathrm{kg}$ per plot of rice during both the years. Amongst zinc application, application of 20 $\mathrm{kg} \mathrm{ZnSO}_{4} \mathrm{ha}^{-1}\left(\mathrm{~S}_{3}\right)$ at the time of transplanting recorded higher mean grain yield $\mathrm{kg}$ per plot (5.38) and straw yield $\mathrm{kg}$ per plot (6.70) over other soil base zinc application treatments but harvest index dose not shows any significant effect. However, it was statistically at par with $\left(\mathrm{S}_{2}\right) \quad 10 \mathrm{~kg} \quad \mathrm{ZnSO}_{4} \quad \mathrm{ha}^{-1}$ at the time of transplanting. Minimum mean grain yield $\mathrm{kg}$ per plot (4.83) and straw yield $\mathrm{kg}$ per plot (6.12) were recorded in control $\left(S_{1}\right) 00 \mathrm{~kg}$ $\mathrm{ZnSO}_{4} \mathrm{ha}^{-1}$.

Foliar zinc application produced significant variation on grain and straw yield $\mathrm{kg}$ per plot.
Treatment $1 \%$ Zn EDTA at tillering and grain filling stage proved significantly maximum mean grain yield $\mathrm{kg}$ per plot (5.31) and straw yield kg per plot (6.59) but harvest index does not show any significant effect. The lowest grain yield $\mathrm{kg}$ per plot (4.88) and straw yield $\mathrm{kg}$ per plot (6.22) recorded under $0 \% \mathrm{Zn}$ EDTA.

The interaction effects in respect of Grain and straw yield $\mathrm{kg}$ per plot and harvest index between variety and soil base $\mathrm{Zn}$ application (V x S), variety and foliar Zn application (V x $\mathrm{F})$, soil base $\mathrm{Zn}$ application and foliar $\mathrm{Zn}$ application ( $\mathrm{S} \times \mathrm{F}$ ) and variety, soil base $\mathrm{Zn}$ application and foliar Zn application (V x S x F) were dose not show any significant effect in individual years of investigation and in pooled analysis.

Soil application and foliar sprays might have made adequate availability of $\mathrm{Zn}$ which has facilitated the growth of the plant, due to its involvement in many metallic enzyme system, regulatory functions and auxin production (Sachdev et al., 1988) increased synthesis and transport of carbohydrates to the sink (Peda et al., 2007 and Muthukumararaja et al., 2012). Wang et al., (2014) and Imran et al., (2015) also reported increase in straw yield with application of $\mathrm{Zn}$. Supply of $\mathrm{Zn}$ in soil base zinc application and foliar sprays might have made adequate availability of $\mathrm{Zn}$ which has facilitated the growth of the plant, due to its involvement in many metallic enzyme system, regulatory functions and auxin production (Sachdev, et al., 1998) increased synthesis and transport of carbohydrates to the sink (Peda et al., 2007, Muthukumararaja et al., 2012 and Wang et al., 2014), initiation of primodial reproductive parts and partitioning of photosynthates towards them (Wear and Haghler, 1968). The favourable influence of applied $\mathrm{Zn}$ on yield may be explained to its catalytic or stimulatory effect on most of the physiological and metabolic process of plants. 
Table.1 Effect of zinc application on grain yield, straw yield and harvest index

\begin{tabular}{|c|c|c|c|c|c|c|c|c|c|c|c|c|c|c|c|}
\hline & \multicolumn{3}{|c|}{ Grain yield per plant } & \multicolumn{3}{|c|}{ Straw yield g per plant } & \multicolumn{3}{|c|}{ Grain yield kg per plot } & \multicolumn{3}{|c|}{ Straw yield kg per plot } & \multicolumn{3}{|c|}{ Harvest index } \\
\hline & Y1 & Y2 & Pooled & Y1 & Y2 & Pooled & Y1 & Y2 & Pooled & Y1 & Y2 & Pooled & Y1 & Y2 & Pooled \\
\hline V1 & 17.81 & 18.21 & 18.01 & 22.44 & 22.86 & 22.65 & 5.09 & 5.21 & 5.15 & 6.42 & 6.54 & 6.48 & 44.10 & 44.19 & 44.15 \\
\hline $\mathbf{V 2}$ & 16.07 & 16.52 & 16.29 & 20.97 & 21.39 & 21.18 & 4.59 & 4.72 & 4.66 & 6.00 & 6.12 & 6.06 & 43.52 & 43.73 & 43.63 \\
\hline V3 & 18.89 & 19.35 & 19.12 & 23.11 & 23.63 & 23.37 & 5.40 & 5.53 & 5.47 & 6.61 & 6.76 & 6.68 & 44.77 & 44.82 & 44.79 \\
\hline S.Em. \pm & 0.50 & 0.52 & 0.36 & 0.48 & 0.50 & 0.34 & 0.14 & 0.15 & 0.10 & 0.14 & 0.14 & 0.10 & 0.94 & 0.96 & 0.74 \\
\hline C.D. & 1.43 & 1.50 & 1.00 & 1.39 & 1.44 & 0.97 & 0.41 & 0.43 & 0.29 & 0.40 & 0.41 & 0.28 & NS & NS & NS \\
\hline S1 & 16.65 & 17.10 & 16.88 & 21.17 & 21.61 & 21.39 & 4.76 & 4.89 & 4.83 & 6.06 & 6.18 & 6.12 & 43.70 & 43.85 & 43.77 \\
\hline $\mathbf{S 2}$ & 17.54 & 17.95 & 17.74 & 22.18 & 22.60 & 22.39 & 5.02 & 5.13 & 5.07 & 6.34 & 6.46 & 6.40 & 44.06 & 44.17 & 44.12 \\
\hline S3 & 18.57 & 19.03 & 18.80 & 23.16 & 23.66 & 23.41 & 5.31 & 5.44 & 5.38 & 6.62 & 6.77 & 6.70 & 44.63 & 44.72 & 44.67 \\
\hline S.Em. \pm & 0.50 & 0.52 & 0.36 & 0.48 & 0.50 & 0.34 & 0.14 & 0.15 & 0.10 & 0.14 & 0.14 & 0.10 & 0.94 & 0.96 & 0.74 \\
\hline C.D. & 1.43 & 1.50 & 1.00 & 1.39 & 1.44 & 0.97 & 0.41 & 0.43 & 0.29 & 0.40 & 0.41 & 0.28 & NS & NS & NS \\
\hline F1 & 16.84 & 17.29 & 17.06 & 21.53 & 21.97 & 21.75 & 4.82 & 4.94 & 4.88 & 6.16 & 6.28 & 6.22 & 43.78 & 43.92 & 43.85 \\
\hline F2 & 18.33 & 18.77 & 18.55 & 22.82 & 23.27 & 23.04 & 5.24 & 5.37 & 5.31 & 6.53 & 6.66 & 6.59 & 44.48 & 44.57 & 44.53 \\
\hline S.Em. \pm & 0.41 & 0.43 & 0.29 & 0.39 & 0.41 & 0.28 & 0.12 & 0.12 & 0.08 & 0.11 & 0.12 & 0.08 & 0.77 & 0.79 & 0.60 \\
\hline C.D. & 1.17 & 1.23 & 0.83 & 1.13 & 1.18 & 0.80 & 0.33 & 0.35 & 0.24 & 0.32 & 0.34 & 0.23 & NS & NS & NS \\
\hline \multicolumn{16}{|c|}{$V \times S$} \\
\hline S.Em. \pm & 0.86 & 0.91 & 0.61 & 0.84 & 0.87 & 0.59 & 0.25 & 0.26 & 0.17 & 0.24 & 0.25 & 0.17 & 1.64 & 1.67 & 1.14 \\
\hline C.D. & NS & NS & NS & NS & NS & NS & NS & NS & NS & NS & NS & NS & NS & NS & NS \\
\hline \multicolumn{16}{|c|}{$V \times F$} \\
\hline S.Em. \pm & 0.70 & 0.74 & 0.50 & 0.68 & 0.71 & 0.49 & 0.20 & 0.21 & 0.14 & 0.20 & 0.20 & 0.14 & 1.34 & 1.36 & 0.94 \\
\hline C.D. & NS & NS & NS & NS & NS & NS & NS & NS & NS & NS & NS & NS & NS & NS & NS \\
\hline \multicolumn{16}{|c|}{$\mathbf{S} \times \mathbf{F}$} \\
\hline S.Em. \pm & 0.70 & 0.74 & 0.50 & 0.68 & 0.71 & 0.49 & 0.20 & 0.21 & 0.14 & 0.20 & 0.20 & 0.14 & 1.34 & 1.36 & 0.94 \\
\hline C.D. & NS & NS & NS & NS & NS & NS & NS & NS & NS & NS & NS & NS & NS & NS & NS \\
\hline \multicolumn{16}{|c|}{$V \times S \times F$} \\
\hline S.Em. \pm & 1.22 & 1.28 & 0.86 & 1.18 & 1.23 & 0.83 & 0.35 & 0.37 & 0.25 & 0.34 & 0.35 & 0.24 & 2.31 & 2.36 & 1.60 \\
\hline C.D. & NS & NS & NS & NS & NS & NS & NS & NS & NS & NS & NS & NS & NS & NS & NS \\
\hline CV\% & \multicolumn{3}{|c|}{12.16} & \multicolumn{3}{|c|}{9.33} & \multicolumn{3}{|c|}{12.16} & \multicolumn{3}{|c|}{9.33} & \multicolumn{3}{|c|}{9.16} \\
\hline & & & & \multirow{2}{*}{\multicolumn{3}{|c|}{$\begin{array}{l}V_{1} \text { - IET-25450 } \\
V_{2} \text { BPT-5204 }\end{array}$}} & \multicolumn{3}{|c|}{$\mathrm{S}_{1^{-}} 00 \mathrm{~kg} \mathrm{ZnSO}_{4} \mathrm{ha}^{-1}$} & \multirow{2}{*}{\multicolumn{3}{|c|}{$\begin{array}{c}\mathbf{F}_{\mathbf{1}^{-0}} \mathbf{0} \% \mathbf{Z n} \text { EDTA } \\
\mathrm{F}_{-1}-1 \% \text { Zn EDTA }\end{array}$}} & & & \\
\hline & & & & \multicolumn{2}{|c|}{$V_{3^{-}}$IET-24766 } & & \multicolumn{2}{|c|}{$\begin{array}{l}\mathrm{S}_{2^{-}} 10 \mathrm{~kg} \mathrm{ZnSO}_{4} \mathrm{ha}^{-1} \\
\mathrm{~S}_{3^{-}}-20 \mathrm{~kg} \mathrm{ZnSO}_{4} \mathrm{ha}^{-1}\end{array}$} & & & \multicolumn{2}{|c|}{$\mathrm{F}_{2}-1 \% \mathrm{Zn}$ EDTA } & & & \\
\hline
\end{tabular}



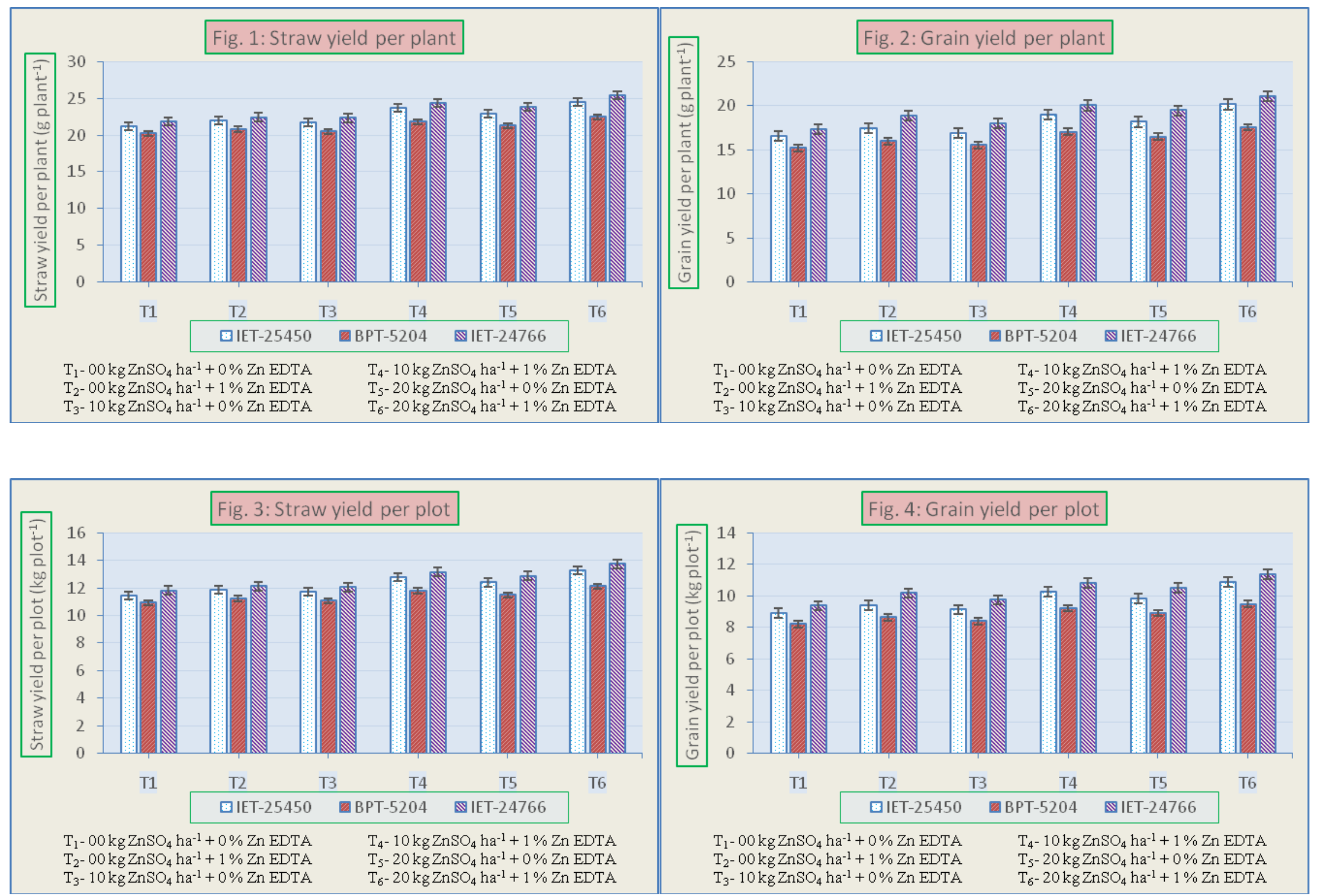


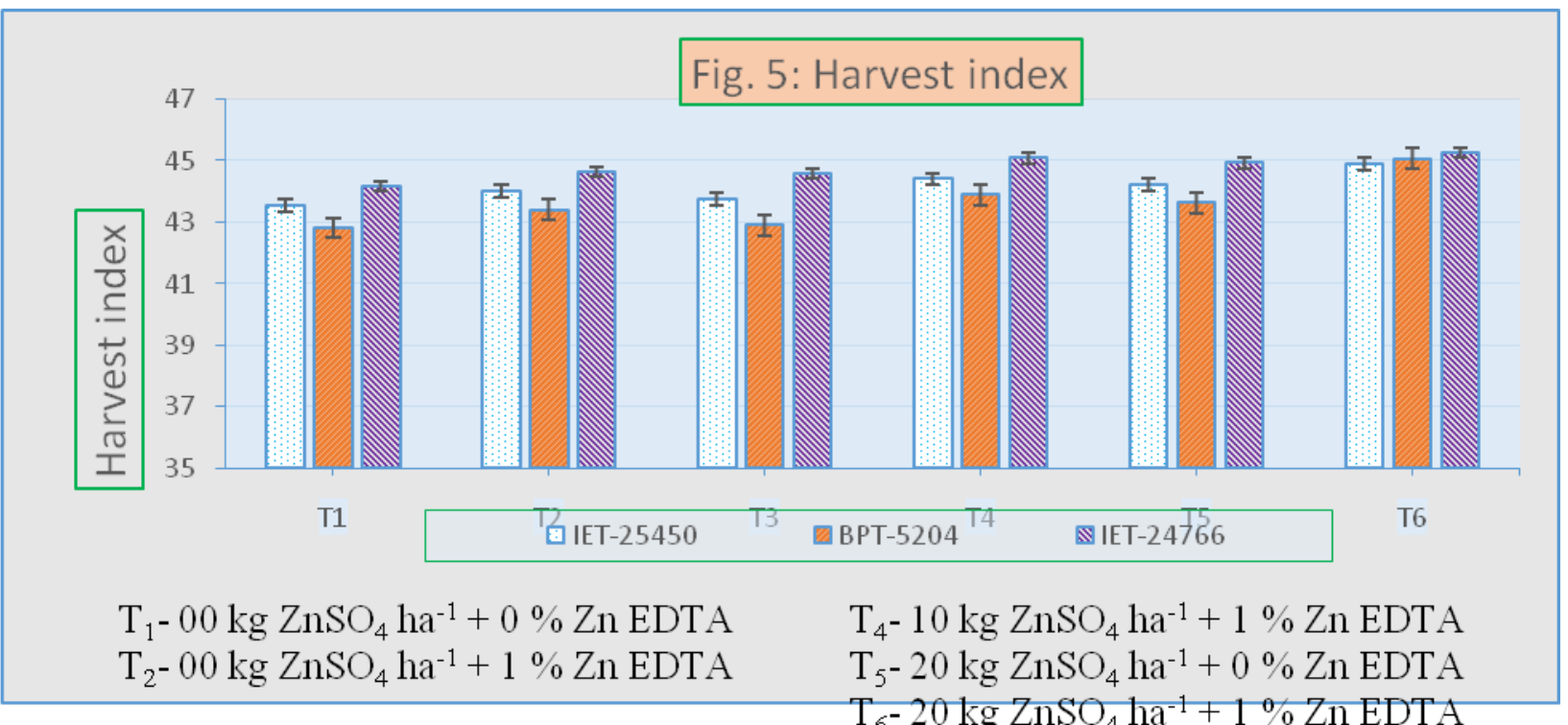

The results are in close conformity with findings of (Goswami 2007 and Singh et al., 2012) also reported that increasing levels of zinc increased wheat yield.

Zinc deficiency in cereal plants, including rice, is a well-known problem that causes reduced agricultural productivity all over the world. The results indicate that there is need for $\mathrm{Zn}$ application (soil or foliar) for better paddy yield either as chelated form or as mineral $\mathrm{ZnSO}_{4}$.It was observed that zinc application has significant positive effect on grain and straw yield and harvest index, among the varieties, IET-24766 recorded significant highest grain and straw yield and harvest index which was followed by IET25450 and BPT-5204. Zinc application had also significant influence on grain and straw yield and harvest index. The soil base $\mathrm{Zn}$ treatment, $20 \mathrm{~kg} \mathrm{ZnSO} \mathrm{ha}^{-1}$ at the time of transplanting recorded significantly higher grain and straw yield and harvest index of rice followed by $10 \mathrm{~kg} \mathrm{ZnSO} 4 \mathrm{ha}^{-1}$ at the time of transplanting and control $00 \mathrm{~kg} \mathrm{ZnSO}_{4} \mathrm{ha}^{-1}$. The foliar application of chelated zinc increased the paddy yield as compared to soil base zinc application. While, foliar $\mathrm{Zn}$ application recorded significantly maximum grain and straw yield and harvest index of rice under $1 \%$ Zn EDTA spray at tillering and grain filling stage followed by $0 \% \mathrm{Zn}$ EDTA. Further study should be needed to elaborate role of zinc at molecular level to strength the knowledge of role of zinc in yield.

\section{References}

Boonchuay, P., Cakmak, I., Rerkasem, B. and Prom-U-Thai, C. (2013). Effect of different foliar zinc application at different growth stages on seed zinc concentration and its impact on seedling vigor in rice. Soil Sci. Plant Nutr., 59: 180-188.

Dobermann, A. and Fairhurst, T. (2000). Rice: nutrient disorders and nutrient management. Potash and Phosphate Institute, Potash and Phosphate Institute of Canada, and International Rice Research Institute.

FAO (2017). FAOSTAT production statistics. Food and Agriculture Organization of the United Nations (FAO).

Fischer, K. S. (1998). Towards increasing nutrient use efficiency in rice cropping systems. Field Crop Res., 56: 1-6.

Gomez, A. K. and Gomez, A. A. (1984). Statistical procedure for agricultural research, second Edition, A Willey- 
International Science Publication, John Wiley and Sons, New Delhi, India, p. 680.

Goswami, (2007). Response of wheat (Triticumaestivum) to nitrogen and zinc application. Ann. Agric. Res. New Series, 28(1): 90-91.

Impa, S. M. and Johnson-Beebout, S. E. (2012). Mitigating zinc deficiency and achieving high grain $\mathrm{Zn}$ in rice through integration of soil chemistry and plant physiology research. Plant and Soil, 361: 3-41.

Imran, M., Kanwal, S., Hussain, S., Aziz, T. and Maqsood, M. A. (2015). Efficacy of zinc application methods for concentration and estimated bioavailability of zinc in grains of rice grown on a calcareous soil. Pakistan Journal of Agriculture Science, 52: 169-175.

Mahmoodi, B. and Mogadam, M. N. (2015). Effect of $\mathrm{Zn}$ application on yield and yield components of rice. Research Journal of Fisheries and Hydrobiology, 10(11): 72-77.

Muthukumararaja, $\quad$ T. $\quad$ M. and Sriramachandrasekharan, M. V. (2012). Effect of zinc on yield, zinc nutrition and zinc use efficiency of lowland rice. Journal of Agricultural Technology, 8(2): 551-561.

Muthukumararaja, T.M. and M.V. Sriramachandrasekharan (2013).

Response of rice genotypes to zinc fertilization in TypicHaplustert soil. Indian Journal of applied Research,3(2): 27-29.

Naik, S. K. and Das D. K. (2007). Effect of split application of zinc on yield of rice (Oryza sativa L.) in an Inceptisol. Arch. Agron. Soil Sci., 53(3): 305-313.

Neue, H. U., Quijano, C., Senadhira, D. and Setter, T. (1998). Strategies for dealing with micronutrient disorders and salinity in lowland rice systems. Field Crops Research, 56: 139-155.

Peda, B. P., Shanti, M., Rajendra, P. B. and Minhas, P. S. (2007). Effect of zinc on rice in rice-black gram cropping system in saline soils. Andhra Agricultural Journal, 54(1-2): 47-50.

Rehman, H. U., Aziz, T. and Farooq, M. (2012). Zinc nutrition in rice production systems: A review. Plant Soil, 361(1-2): 203-226.

Roemheld, V. and El-Fouly, M. M. (1999). Foliar nutrient application: Challenge and limits in crop production. Proc. 2nd International Workshop on Foliar Fertilization, April 4-10 Bangkok, Thailand, pp. 1-32.

Roohani, N., Hurrell, R., Kelishadi, R., Schulin, R. (2013). Zinc and its importance for human health: An integrative review. Journal of research in medical sciences: the official journal of Isfahan University of Medical Sciences, 18(2):144.

Sachdev, P., Deb, D. L. and Rastogi, D. K. (1998). Effect of varying levels of zinc and manganese of drymatter yield and mineral composition of wheat plant at maturity. Journal of Nuclear Agriculture and Biology, 17(3): 13743.

Sadeghzadeh, B. A. (2013). Review of zinc nutrition and plant breeding. Journal of Soil Science and Plant Nutrition, 13: 905-927.

Savithri, P., Perumal, R. and Nagarajan, R. (1999). Soil and crop management technologies for enhancing rice production under micronutrient constraints. Nutr. Cycl. Agro Ecos., 53: 83-92.

Shivay, Y. S., Kumar, D., Prasad, R. and Ahlawat, I. P. S. (2008). Relative yield and zinc uptake by rice from zinc sulphate and zinc oxide coatings onto 
urea. Nutr. Cycl. Agroecosys, 80: 181188.

Singh, M. V. (2009). Micronutrient nutritional problems in soils of India and improvement for human and animal health. Indian Journal of Fertilisers, 5(4): 11-56.

Singh, O, Kumar, S. and Awanish (2012). Productivity and profitability of rice as influence by high fertility leves and their residual effect on wheat. Ind. $J$. Agron, 57(2): 143-147.

Wang, Y. Y., Wei, Y. Y., Dong, L. X., Lu, L. L., Feng, Y. and Zhang, J. (2014).
Improved yield and $\mathrm{Zn}$ accumulation for rice grain by $\mathrm{Zn}$ fertilization and optimized water management. Journal of Zhejiang University Science, 15(4): 365-74.

Wear, J. L. and Hagler, T. B. (1968). Plant food review. Spring.

Yuan, L., Lianghuan, W. Chunlei, Y. and Qian, L. V. (2013). Effects of iron and zinc foliar applications on rice plants and their grain accumulation and grain nutritional quality. J. Sci. Food Agric., 93: 254-261.

\section{How to cite this article:}

Vivek N. Zinzala and Ajay V. Narwade. 2019. Effect of Zinc applications on Grain Yield, Straw Yield and Harvest Index in kharif Rice (Oryza sativa L.) Genotypes. Int.J.Curr.Microbiol.App.Sci. 8(11): 27-35. doi: https://doi.org/10.20546/ijcmas.2019.811.004 